\title{
The Incomplete Domestication of Wauja Women
}

\author{
EMILIENNE M. IRELAND \\ Smithsonian Institution | Washington DC, United States of America \\ ireland.emi@gmail.com
}

DOI 10.11606/issn.2316-9133.v30i2pe193357

\begin{abstract}
In 1981, the Wauja women of Central Brazil, despite burdens they endured due to their gender, nevertheless enjoyed certain freedoms that men did not. Among these were greater freedom of movement around the village, and freedom to speak privately with women from any household. These freedoms were not trivial, and gave women privileged access to information of all kinds ("gossip"). In this way, women were able to shape community perception of events in ways that men could not. Women's labor and economic contribution, in those days, was considered as essential as that of men. Four decades later, Wauja women no longer exchange news with other women as they walk to the river together to draw water. Instead, access to information is increasingly shaped by digital devices, which many young married women do not own. These women often live as their husbands' economic dependents, because men earn salaries and control the bank accounts. How did women's lives change so much in a single generation, and how are Wauja women responding?
\end{abstract}

keywords Xingu, Arawak, gender, sexuality, patriarchy, schooling, rank

\begin{abstract}
A domesticação incompleta das mulheres Wauja resumo Em 1981, apesar dos fardos que suportaram devido ao seu gênero, as mulheres Wauja do Brasil Central gozavam de certas liberdades que os homens não gozavam. Entre elas havia maior liberdade de movimento pela aldeia e liberdade para falar em particular com mulheres de qualquer casa. Essas liberdades não eram triviais e davam às mulheres acesso privilegiado a todos os tipos de informações ("fofoca"). Dessa forma, foram capazes de moldar a percepção da comunidade sobre os eventos de uma forma que os homens não conseguiam. O trabalho e a contribuição econômica das mulheres, naquela época, eram considerados tão essenciais quanto os dos homens. Quatro décadas depois, as mulheres Wauja não trocam mais notícias com outras mulheres enquanto caminham juntas até o rio para buscar água. Em vez disso, o acesso à informação é cada vez mais moldado por dispositivos digitais, que muitas mulheres jovens casadas não possuem. Essas mulheres muitas vezes vivem como dependentes econômicas de seus maridos, porque os homens ganham salários e controlam as contas bancárias. Como a vida das mulheres mudou tanto em uma única geração e como as mulheres Wauja estão respondendo?
\end{abstract}

palavras-chave Xingu, Arawak, gênero, sexualidade, patriarcado, escolarização, posição 


\section{Introduction}

This essay sketches some aspects of life for Wauja women in 1981, when I first resided in their community, as compared to the lives of their daughters and granddaughters four decades later, in 2021. Among the Wauja, attributes such as relative seniority and inherited rank can determine the nature of interaction between two people as much as gender, if not more. In addition, in recent years, something resembling socio-economic class inequality has become apparent in a community that only four decades ago had an economy that insistently demanded the recirculation of objects (whether by sharing, payment, exchange, or confiscation), preventing accumulation of material wealth by individuals or families. I ask the reader to keep in mind, therefore, that looking at women's lives in terms of gender is only the beginning of the discussion.

\section{Wauja women in the early 1980s}

When I first lived among the Wauja, I asked whether women held positions of village leadership. Men and women both said no. Women can be shamans and ceremonial leaders, they can inherit chiefly rank and pass it to their heirs, and they can exercise influence and authority in many aspects of village life. Even so, the Wauja insisted that women have no role in the political leadership of the village, in the chief's exercise of power, in decisions that affect the village as a whole, and particularly, in serious matters among men, such as factional disputes or accusations of witchcraft. Indeed, in public situations, women were not always accorded the same degree of personal dignity as men. Men would point out that women were gossips and, unfortunately, inveterate troublemakers. "She's a woman, so that's why she lies" (toneju, oukaka minyulipai), they would usually add, quoting a classic Wauja proverb. ${ }^{1}$

Despite the relatively low public profile of Wauja women, it was clear to me that, in those days, they enjoyed certain enviable privileges and protections that most women in my own society did not. Women's economic contribution was respected and seen as essential, and just as important as that of men. Women controlled what they produced. If a woman made a hammock or a ball of cotton yarn, she could trade it away, or give it to a person of her choosing. It did not belong to her husband or anyone else. Men, likewise, controlled what they produced. Of course, all adults were expected to contribute to providing food and other necessities for their own household group, and for ritual obligations to the community. However, no woman was dependent on her husband more than he was on her. If a woman became widowed, she need not suffer hunger and want. She simply continued to contribute her valuable labor to her own household group, or she could join another household as a co-wife.

\footnotetext{
${ }^{1}$ This proverb is offered matter-of-factly, often with a chuckle of resignation. It should be noted that the term minyulipai ("to lie") carries none of the strong negative moral connotations in Wauja that it carries in English. The Wauja generally consider that an individual is at liberty to tell the truth or prevaricate, as seems appropriate for the situation. For example, in response to an impertinent question, lying is the most polite response. In this view, only a foolish or quarrelsome person insists on telling the truth in every situation.
} 
Another benefit enjoyed by Wauja women was uxorilocality, and more generally, co-residence in extended family groups. Husbands would hardly dare to abuse their wives in the presence of the woman's parents and unmarried brothers. When I asked the Wauja about whether husbands ever used physical violence against their wives, they thought the question was strange. "Why would anyone injure his own wife? Who would help him tend the crops? Who would make bread for the children to eat?" Even women who married into their husband's households were protected by the constant presence of their in-laws, together with the Wauja's strong aversion to open conflict.

Violence against women was then and continues to be quite rare. During my eighteen months' residence from 1981-83, there was only one incident of a woman being struck by man. A young man in a jealous pique gave his wife several thumps on her back with the side of his fist, also pulling her hair. Significantly, this did not occur in their household, but outdoors in the central plaza, where his behavior was sharply criticized by the elder women who were present. That night, the young man's father, with whom the couple lived, expressed intense shame and displeasure, saying that if this occurred again, they should live elsewhere. Meanwhile, certain male rivals of the young man lost no time sharing the details of how he had completely lost his composure and made a fool of himself in public. $^{2}$

Although it was unheard of for a woman to be physically abused in her home, she had to avoid being alone while away from the village. For example, if a woman found herself walking alone to fetch water from the river, out of earshot of the village, a passing man might grab her firmly by the wrist and lead her into the forest to have sex. Women despised such encounters and generally avoided them by taking care to walk to the river with children or other women. In any case, a woman certainly never had reason to fear that she might be raped and then murdered, something that can happen to a woman in any urban society.

Normally, however, sexual contact was consensual and considered enjoyable not only to engage in, but also to gossip about. When in a mood for candid reflection, women expressed a range of opinions about the pleasure they derived from sex. Some women said that their initial experience of penetration had hurt, yet women often expressed evident pleasure and excitement in anticipation of meeting with a lover. ${ }^{3}$ I was told that some

\footnotetext{
2 There was not a complete absence of more serious violence against women, however. In living memory spanning about seventy years, there are two reported instances of ritually sanctioned gang-rape among the Wauja, each allegedly because a woman violated the rule against seeing the sacred kawoká flutes. One occurred roughly in the second quarter of the twentieth century, and the other in the 1960s. This practice has been reported for other Upper Xingu groups (Gregor, 1985:103-104; Basso 1985:306) and should not be conflated with rituals in other groups in which women, whether willingly or not, have sequential sex with a group of men and do not suffer permanent disgrace and destruction of their social identity as a result (e.g., Crocker and Crocker, 2004: 109; Lea, 2013).

${ }^{3}$ In those days, as a young woman, I was privy to the goings-on between young lovers. As the ideal go-between, I visited men and women in every house, didn't spill secrets, and could deliver a bar of soap or another gift without arousing any suspicion. Now, four decades later, I am totally out of the loop, as those in the most sexually active age group all call me auntie or grandma, and would consider it very unseemly to confide in me about sexual matters. This is an example of how relative seniority affects the expression of gender relations.
} 
women like to leave the uluri belt on during sex so that the little string that passes between her legs can enhance the sensation. On one occasion, an older woman chatting with a group of her peers confessed, "When my toe is tickled, I simply lose my judgement," occasioning screams of laughter. When I asked what was so funny, the women stared at me, nonplussed, until at last I understood. The Wauja are well aware that the clitoris is a key locus of sexual pleasure in women, which may support the idea that Wauja women do experience sexual pleasure, even if they prefer to be discreet about it, especially when talking to anthropologists. ${ }^{4}$

As has been reported for other Upper Xingu peoples, most Wauja men and women cultivated extramarital lovers. This was considered a normal part of adult life, so long as the partner was in the approved kinship category (cross-cousin) and provided the affair was conducted discretely, so as not to upset one's spouse. Among the Mehinaku, a closely related community of fellow Arawak-speakers, Gregor suggests that extramarital attachments "contribute to village cohesion" and "enhance community stability by promoting enduring relationships based on mutual affection" (1985: 37). Gregor surmises, however, that men's and women's motivations for initiating affairs differ, with men motivated principally by sexual desire, and women by social contact, gifts, as well as the physical side of the relationship (1985: 36). Franchetto likewise acknowledges the economic importance of these affairs: "extraconjugal relations form a complex, diffuse, and vital network of parallel exchanges" (1996: 232). Yet she also sees in them women's desire for agency, autonomy and control, constituting a "domain where women exercise surprising autonomy, both individual and collective. In this domain they control their own wealth: their bodies, their sex, their goods" (1996: 232).

I agree with Franchetto's point and would suggest an additional motivation for these affairs: revenge, or simply "evening the score." If a man learns that a rival is making love to his wife, it is likely he will attempt to seduce his rival's wife, while giving his own wife something to think about. Sometimes this is done in a light-hearted way. I remember writing up my notes in an empty house during Kaumai ${ }^{5}$, a large intergroup festival, while my housemates were all out enjoying themselves. Suddenly one of the men entered the house, with a worried look on his face, asking whether I had seen his wife. Alas, I had not. He went out as quickly as he had entered. Soon enough, he returned, wearing a wide grin. "I got my own back!" (nikiyuntuapawi). This kind of good-natured and open tolerance of a spouse's occasional extraconjugal relations is no longer the norm today, as shall be discussed below.

It should be noted that a man's rivals for women are often his rivals in other things, such as positions of leadership in political and ritual domains. These rivals are primarily his cousins, half-brothers, and sometimes even his full brothers. During my fieldwork, I found that a man's factional rivals often were the very same men who were his wife's extramarital

\footnotetext{
${ }^{4}$ The Wauja in those days referred to the clitoris matter-of-factly, with a plainly descriptive Wauja term that glosses as "nose of the genitals" (otokiritsi).

${ }^{5}$ Kaumai is the Wauja term for the mortuary ceremony that is called Kwarup by their neighbors.
} 
lovers. Even without being told, men often knew or could surmise who their wife's lovers were. Doubtless this added fuel to any competitive resentment they may have already felt. However, while the man may have felt doubly resentful, the woman often had mixed loyalties and would not want the men to quarrel. After all, she well knew that either of them could be the father of her children. In this way, sexual affairs caused some feelings of jealousy but at the same time created bonds of affection and kinship. In the early 1980s, most Wauja men took a philosophical attitude to ties to other men through their wives' extraconjugal relations. As one man explained it, "You have a child and you raise him, caring for him every day. He calls you papa. Then one day you notice he looks a lot like your cousin across the plaza. It's OK. He's still your son."

In long-standing extraconjugal relationships, the mother's lover sometimes formed strong attachments to the child. When I asked one woman about her childhood, she told me that both her parents had died in the 1954 measles epidemic, leaving her an orphan while still a young child, but that one of her uncles saved her from going hungry. He approached her and said, "You are my daughter. I was your mother's lover; I made you. Come to my house to eat fish whenever you are hungry." And so she did. Reflecting on this story, I was impressed that the man's wife (who portioned out the fish) honored her husband's tie to a child he fathered with a woman who presumably had once been a rival for her husband's affections. ${ }^{6}$ I found that strong attachments and generous behavior toward the child of a lover are common. In 2018, an elderly man asked me to bring him a wallet-sized image of his lover, who had died nearly fifty years earlier. On the day I brought it to him, he happened to be making a fine shell necklace for the woman's daughter, who is now a grandmother herself.

In those days, Wauja women had relatively little control over their fertility. Although they sometimes took traditional infusions to prevent pregnancy, they knew the medicines often didn't work. Women were married soon after their first menstruation, normally in their mid-teens, and by their mid-thirties they typically had already borne six to nine children. If frequent childbearing was burdensome for women, childcare was much less so. Living in large households with extended family - as many as 20-30 people - made childcare much easier. Young couples usually lived with the wife's family, which meant that a woman's mother and sisters lived with her in one communal house. Typically, there also were older children present who could be called upon to entertain and watch over toddlers and young children. It should be noted that most Wauja fathers were then, and still are, exceptionally attentive and patient parents.

\footnotetext{
6 Gregor (1977: 292-94) provides detailed examples of how notions of partible paternity affected kinship behavior across generations. Note that since Gregor's initial research in the 1970s, the Wauja and other Upper Xingu groups, after decades of exposure to Christianity and other aspects of Brazilian national culture, tend to avoid acknowledging partible paternity, unlike a generation ago. In contrast to Gregor's focus on the relationship between secondary fathers and the child, some recent literature on partible paternity focuses on male strategies to increase reproductive success or simply access to sex: "secondary fathers adopt co-paternal care (i.e., friendships with the mother and her offspring) as a strategy to compete with primary fathers to get differentially improved mating access" (Weight and Keefe, 2016: 96).
} 
The Wauja preference - in those days - for young married couples to live in the house of the wife's father also gave those women who happened to have inherited rank access to advanced training in the kinds of knowledge that earned high prestige and handsome payments. Here we see an example of how rank could influence life opportunities, trumping gender. A young man born into a home of 'commoner' rank (iyataku) could expect to learn from his father how to provide food and shelter for his family, as well as how to be a respectable community member. Normally, such a man would marry a woman of similar rank, and so reside with his wife's family in a household headed by a man of commoner rank. In such households, there typically was little or no training in the most valued forms of traditional knowledge. In contrast, for men and women born to parents of high inherited rank (amunãu), such as village chiefs and the sons and daughters of prior village chiefs, advanced training was received at home, at the knees of parents and grandparents. For this very reason, until recently, the sons of chiefs did not marry until about thirty years of age, because they were expected to undergo rigorous tutelage under their father's supervision. Were a chief's heir to marry at age twenty, he would have to live in his father-in-law's house, who often would be chief in a neighboring ethnic community, such as the Yawalapiti, Kamayura or Mehinaku. The father-in-law would most likely prefer to teach his own sons as opposed to his son-in-law, who, being from another ethnic group, would probably not yet speak his wife's language fluently. As a result, the most powerful men did not allow their heirs to marry early.

Women married in their mid-teens but unlike men they typically did not have to leave the home of their parents. As a result, even after marriage, high-ranking women could continue their specialized training under the tutelage of parents and grandparents indefinitely. A woman of inherited rank (amuluneju) who showed aptitude and interest could receive lifelong training from her father in oral literature, magical incantations, sacred ceremony and songs, and other valuable skills. Perhaps the most high-prestige types of learning for men or women are that of a tobacco shaman (yatamá, yatamalu) and an even rarer skill, the ability to see spirits and witches (yakapá kujutaixei). The Wauja say that a person does not choose to become a shaman but is instead chosen by a spirit that makes them sick and then, if placated, allows the ailing person to recover and tutors them. Nonetheless, in 1981-83 there were only two such Wauja women, both daughters of highranking chiefs. We should not be surprised that the midwife in 1981-83 was also the eldest daughter of the prior Wauja chief, Tupataritsumpa. ${ }^{7}$

One may ask, why did village chiefs spend years training their daughters, when women were never eligible to become chief? In my observation, Wauja fathers often had a close emotional attachment to an adult daughter they tutored. ${ }^{8}$ Furthermore, a Wauja

\footnotetext{
${ }^{7}$ Aline Regitano's description of the leading midwife among the Mehinaku in 2017 fits this pattern: "daughter of an herbalist mother and her father a village leader, mother of six girls and grandmother to two more, she was born a leader, trained by her father and recognized by her people, thus accumulating characteristics of a 'wise person' or specialist." (2019: 63).

${ }^{8}$ As a researcher, I benefitted from this tradition, in which pre-eminent Wauja intellectuals of all kinds (storytellers, historians, shamans, and ritual specialists) viewed women as worthy of comprehensive tutoring.
} 
woman who is the eldest daughter of the village chief has a civic responsibility to lead the other women in sacred song and ceremony. Finally, as is symbolically announced by the large and prominent uluri belt clasp of a type that only the highest-ranking women wear, the issue of such women inherit her rank and are expected to be future village chiefs. It is striking to note that of the hundreds of recordings I made of traditional tales, historical narratives, sacred songs, ceremonial performances, incantations to heal or to harm, and shamanic trances - in all of them, people of inherited rank were repeating information they personally had been taught by a village chief (kehoto yekeho) or co-chief (amunãu opalukaka), or by the son or daughter of that chief or co-chief. This concentration of knowledge is not the result of sampling error. Carlos Fausto has documented the same tendency for knowledge concentration among the Kuikuro, where "families of singers tend to form, with musical knowledge passing between kin, and especially from parents to children" (2016: 144).

People who were of so-called 'commoner' rank shared with me practical knowledge, life histories, and many other kinds of information. However, although commoners may have been somewhat familiar with Wauja oral literature and music, they were not considered qualified to perform them unless they had been personally trained by a 'qualified' person. Chiefs passed on their specialized knowledge to their heirs as a parental and civic duty, without being paid. But if a commoner wanted to learn such things, they had to pay to be tutored. Alas, the cost was prohibitively high for commoners, who did not already possess specialized knowledge that allowed them to command payments, such as song master (apai yekeho), incantation master (ejekeki yekeho), master of herbalism (ataga wekeho), or seer of spirits and witches (yakapá), to name a few.

As a result of residence patterns, Wauja women as a group had more years of opportunity to learn from their own parents than did their brothers, who had to leave the parental home when they married. In addition, because of Wauja traditions of concentrating specialized knowledge among families with high inherited rank, some Wauja women had far greater access to this knowledge than did most men. There were more than a few such women. Because prominent high-ranking men such as village chiefs usually had two or three wives, they tended to have more children than commoners. In 1981, out of 28 adult women, 15 women, or roughly half, were either eldest daughters of village chiefs and co-chiefs, granddaughters of village chiefs, or both. These high-ranking women had significant advantages in specialized training that commoner men and women did not.

Another kind of advantage that Wauja women had in 1981 was freedom of movement about the village. In the literature on Xingu peoples, it is often noted that women do not stroll casually through the central plaza, and that they absolutely may not enter the men's house where the sacred flutes are stored. However, despite the impressiveness of the men's flutes, we should not forget that the plaza and the men's house were the only places women could not freely wander. For men, by contrast, it was unseemly to visit other men's houses except on ceremonial occasions or unless the two men had very close ties. In other words, while a woman could visit any house except the men's house, and not casually stroll about the central plaza, a man had to stay out of all the houses except his own and perhaps 
one or two others, at most. Significantly, the places where men most often socialized with men from other households - the plaza and the men's house - were in full public view. ${ }^{9}$

When a man needed to borrow something from a man in another house, he would send a child to ask for some beeswax or whatever was wanted. Otherwise, if a man was seen going to another man's house, he might be thought to be attempting to flirt with the women of that house, or perhaps something more sinister. Respectable men were not seen wandering into other men's houses. In contrast, a woman who needed something from another woman would be just as likely to go herself, for the pleasure of a chat in addition to accomplishing the errand. Unlike men, women could always drop by any house in the village on the pretext of inviting one of the women in that house to go fetch water together, which women commonly did several times a day. As a woman, I frequently took advantage of this pretext, in order to have private and candid conversations with women in households other than my own. My invitation was usually accepted, because water was always needed and women didn't like going to fetch water alone, as mentioned above. My companion and I would chat as we walked along the long straight path to the river, then enjoy a refreshing bath, and continue the conversation as we returned, carrying heavy cauldrons of water on our heads for roughly a mile. When we arrived at the village, we parted ways, each carrying our precious burden to our own household. Such private chats between women were one of the best ways to hear gossip about what was going on in the village.

Early in my research, I was eager to learn the language so that I could understand what was being discussed in the men's house. I was convinced that discussions of great political import took place there. But as I began to understand the conversations around me, I was disappointed to discover that politically significant topics virtually never came up at the men's house. It was always the same predictable mix of reports on work activities of other villagers, on current and future fishing prospects, the weather, events in neighboring groups or at the Post, and sexual jokes. Ironically, while men's houses in lowland South American societies have often been viewed as a locus of male solidarity and hence political dominance, in the Wauja case, the men's house is more like a public fishbowl, serving mainly as a place to see and be seen, and to consume food among men, rather than as a political meeting house where serious issues are thrashed out. Unlike men sitting in the men's house, whose every word and gesture occurs under the public gaze, women who walk to the river together to draw water can speak with more privacy than anywhere in the village itself, where eavesdropping is commonplace.

Women were not merely passive conduits of gossip, however. I have seen them actively shape critical information to protect their interests or those of their kin. In one instance, the chief was deathly ill with an abscessed jaw, and there was terrible tension in the village, because it was assumed that the witch who had caused the chief's illness would soon be identified. I was living in the chief's house at the time, and so I was surprised when the eldest daughter of the chief's main rival entered the chief's house to ask after his health.

\footnotetext{
9 The assumption "that culture and social rules constrain women, but not men" is one of the sources of analytical bias that Overing mentions in her classic article (1986:140).
} 
Although her kinsmen were precisely those most likely to be in danger should the chief die, it nevertheless was technically appropriate for her to visit the sick chief as a public display of civic duty. It should be emphasized that neither the chief's rival himself nor any of his four grown sons dared enter the chief's house without specific invitation. Only the daughter, as a woman, had this liberty. She sat beside his hammock, expressed her concern, and politely inquired who exactly might be responsible for causing his illness. The chief replied that the culprit had been revealed to him in a vision and described enough of his vision to make it clear that he was talking about the woman's own husband, without naming him directly. She soon took her leave of the chief and returned to her own household. To my great surprise, however, I soon began to hear gossip that the chief had identified a completely different individual - a notorious Wauja witch who was living in exile far away among a different ethnic group, the Ikpeng. She had cleverly used a play on words, quoting a phrase that the chief had used that happened to match the Ikpeng man's name. By the time the chief's own version began reaching the ears of the villagers, she had succeeded in spreading enough confusion to divert suspicion from her husband long enough to buy time until the chief recovered. After this incident, I asked the Wauja whether women often deliberately distort important information. "Of course," they replied, explaining that because of this, you never know whether to believe a piece of information or not, because you can't be sure that someone hasn't made it all up. "She's a woman, so that's why she lies," they would often add matter-of-factly, quoting the Wauja proverb. But as Franchetto has observed, "To lie is to create, and it is power" (1996: 228).

\section{Forty years later: Wauja women in 2021}

Nowadays, women's lives are, in some ways, more difficult and circumscribed than they were in the past. Today's young women have far less access to economically valued kinds of training than their forebears. When schools and literacy were first introduced, only the elementary grades were taught. To complete secondary school, students had to attend schools in nearby border towns. Because parents were reluctant to send their 14-year-old girls to live alone in border towns, only boys were able to pursue the new kind of education that led to a salaried job as village teacher, health worker, or administrator. Today, nearly all Wauja teachers and other salaried workers are male. In the main village, until recently, there was only one female teacher among more than a dozen males - and she had to quit because her husband did not approve.

Unequal access to this new kind of education also has affected residential patterns. Young men who earn salaries as teachers and health workers are considered prime candidates as marriage partners. In most cases, however, these young men are not interested in living with their wife's family or performing bride service, so a young wife may end up living as an economic dependent in her husband's house. He has the bank account and controls the money. Many young women have no say in how money is spent. Even if she makes handicrafts to sell, it is her husband who goes to the city to sell them, and she must accept his word for how much money he received. If she has less schooling than he, which is usually the case, she is reluctant to demand an accounting. 
Of course, these new-style nuclear family households have none of the childcare advantages that women had when they lived with their mothers and sisters. I have not heard of any incidents of husbands physically mistreating their wives, but young wives nowadays have little leverage over a husband who displeases them. In the old days, a woman could withhold the essential products of her labor. She could decide not to make her husband a new hammock to replace one that was embarrassingly worn-out and uncomfortable. If she did not feel like spinning cotton to make him armbands, he would have to appear in public with old and unsightly ones. She could forget to make fresh porridge, which meant he would have only day-old, slightly rancid porridge to drink between meals. She could refuse to go to the river with him to bathe, an unmistakable public statement that would surely cause older relatives to intervene and question them both about the problem in their marriage. ${ }^{10}$ Men, of course, were also essential providers and could apply pressure in comparable ways. While men and women might obtain some needed items from other family members or through trade, husbands and wives in the old days generally took care not to displease one another.

Nowadays, however, women are marginalized as wage-earners in an increasingly cash-based economy. Many a young wife is economically dependent on her husband and there is nothing she produces with her labor that he can't buy himself with the money he makes. He can buy his own hammock, cotton yarn and even food. He doesn't need her approval or consent. Although most young Wauja men are kind husbands and want their wives to be content, it is still galling to the wives that, compared to their mothers' generation, their economic contribution to the household is seen as unequal to that of their husbands. Their mothers could make most things they needed with their own hands and could trade for the rest. The younger generation of women needs things for their children and themselves that require money, and in nearly all instances, only men earn money. Additionally, Marina Novo (2019) has described some effects that government cash transfer programs such as rural retirement (aposentadoria rural), family grant (Bolsa Família), and others have had on Kalapalo people, who are neighbors of the Wauja. She reports that because Kalapalo women do not know how to deal with cards, banks, and passwords, they depend on men to access the money and hence have less say in how it is spent (Novo, 2018: 153). As in the Kalapalo community, most Wauja elders and women with young children are beneficiaries of these programs (first instituted in 2003); here too, since few have bank accounts that they monitor and control, a husband or younger male relative who has been to school controls the money that women "receive" as beneficiaries.

Women's access to and ability to shape information has changed dramatically. Women no longer walk to the river to draw water and exchange gossip. Because agricultural pesticides from nearby soy plantations were beginning to enter the river where the Wauja drew water, a water filtration system connected to a clean underground water source was

\footnotetext{
${ }^{10}$ I learned this when I asked my husband to go by himself for the morning bath at the river so I could write up some notes while they were fresh. This occasioned our being called aside and questioned by elders regarding why we were quarreling and what was the problem, as well as admonishments to always bathe together every morning and to behave in public as a married couple should.
} 
installed, and women now get water from a spigot right outside each house. One unfortunate result, however, is that women no longer have a frequent excuse to take a long walk and exchange information (gossip) with women from other households. While it is true that the Wauja village of forty years ago was much smaller, both in size and population, than the present village, it is still striking that women today, unlike those of forty years ago, cannot name exactly who lives in the houses on the other side of the village, about 300 meters away. This access to information is also now shaped by digital devices. Although most young single women get their fathers or brothers to buy them cell phones, married women usually don't have cell phones or computers, because husbands tend to control the money, and may not want their wives to learn too much about their activities on social media. Thus, the current generation of young wives has less access to the Internet and to literacy tools in general than do men. However, when today's young single women - without exception, all avid users of Internet technology - eventually get married, it seems unlikely that they will give up their cell phones and Internet access. These young women are learning to gather information not only about their village, but about the world, and to share it not only with other women, but also with young men in their age group. ${ }^{11}$

Forty years ago, some Wauja spoke multiple Indigenous languages but nobody at all spoke Portuguese. Today, there is a generation of young adults who are fluent in both Wauja and Portuguese. As is typical for most small Indigenous groups, Wauja men have more direct personal contact with members of national society than do the women. Men, far more than the women, have opportunities to interact with non-Indigenous people they encounter at university, or when they travel to border towns to buy supplies or sell their hand-made goods. Perhaps as a result, Wauja men - more than the women - seem to have absorbed some of the values of national society.

Young Wauja men have privately told me that their Christian friends say it is wrong for married women to have lovers, that husbands should not allow that, and that a man who allows that is an idiot. Of course, these same young Wauja men believe it is fine for them to have extraconjugal relations, just not their wives. This imported machista ideology has already started to affect Wauja women's lives (cf. Lea, 2013: 90). I recall how, in 1989, I was in the Wauja village with my young son, who was a baby at the time. The Kaumai ceremony was taking place in another village, and all the Wauja were happily making preparations to attend. Because I was a nursing mother, I stayed behind in the village with about five other mothers of infants, and one old man. Everyone else went, young and old, men, women and children. Kaumai is the most important, most festive, and most sacred of ceremonies throughout the Upper Xingu region. People tell me they look forward to it all year. It includes athletic competitions, dancing, feasting, song, and, in the privacy of the forest, some trysts between people from different villages.

\footnotetext{
${ }^{11}$ Because of Covid, a Brazilian NGO determined that Internet connectively was a medical necessity for all Indigenous villages in the region. In the past, only the largest villages had connectivity, and a very weak connection at that. Today, young Wauja in five villages communicate with each other and with contacts in Brazilian cities and abroad via email, private texts, and daily online chat groups.
} 
Three decades later, in 2018, I was present at another Kaumai ceremony, but this time the Wauja were the hosts. I watched as guests from other villages arrived. Many of them seemed to be young men, slowly rolling in on motorcycles. It appeared that less than a quarter of the guests were women, unlike the Kaumai ceremonies I remembered. Meanwhile, I saw some of the young Wauja husbands patrolling the area around their houses, making sure the women stayed inside, and that male guests from other communities stayed away. This was totally unlike the festive and joyous atmosphere of Kaumai in former times. Instead of having their own amorous adventures, these young men spent their time nervously guarding their wives, making sure they didn't celebrate the old-fashioned way, either. I asked some of the young women about this, and they said they often didn't bother attending Kaumai in other villages, because their husbands were jealous, or simply preferred that they stay home. Because many young husbands have adopted the idea that a husband must control and limit his wife's sexuality, they are reluctant to allow their wives to attend Kaumai, the most important ceremony of the year. The women stay home; it would seem that they have been domesticated.

Outside the realm of extraconjugal relations, however, most young husbands don't try to control their wives. Young women nowadays generally prefer to have smaller families than those of their mothers. One man in his mid-thirties would like a second child, but his wife wants to wait five years before another pregnancy, so he is honoring her wishes. He is a respected teacher and the sole breadwinner of his household, but he says he values his wife because she is wise and always gives him good counsel. Another young husband, who also works as a village schoolteacher and has earned a master's degree in anthropology, is tutoring his wife, who despite being a mother of young children, is transcribing and translating old recordings of Wauja elders, including her own late great-grandfather.

Despite all these changes, the old traditional kinds of knowledge, which women continue to learn from their parents and grandparents, are still valued, though the mechanisms of passing on this knowledge are changing. For example, in the old days, only a handful of high-ranking women were song specialists (apai yeketsu). Only they knew these songs perfectly, and they led the other singers, who followed as best they could. When I asked the women why so few knew the songs well, they said that the song specialist does not share her knowledge without receiving payment. The ritual song cycles are long and complex, using obscure and archaic terms that are not heard in everyday speech. Certainly, the songs would be difficult to learn only by hearing them once a year or less. And even if someone managed to learn them simply by listening, they would not have the right to perform them without being formally trained by a song specialist.

In 2021, a young Wauja filmmaker sent me his documentary showing how young people are learning the old songs. In one clip, I was thrilled and amazed to see about thirty young women dancing in the plaza and all singing confidently in unison, pronouncing every word. Obviously, these women had all thoroughly learned the songs. The filmmaker explained that the women had all contributed to pay the song specialist a handsome fee for the right to record this song cycle in its entirety, memorize it from the recording, and - a critical right - to perform it publicly (Waurá, 2021). While the song specialist probably will 
never again receive payment for teaching these songs, she has ensured that they will continue to be learned and expertly performed for many years.

In December of 2021, some high-ranking young Yawalapiti women (granddaughters of a renowned Wauja female shaman who bore and raised two chiefs in the Mehinaku community into which she married) launched the Centro de Convenções de Mulheres do Alto Xingu, the first of its kind in the region. It consists of a large meeting house built in the style of a traditional Xingu longhouse and is not located in any of the Indigenous villages. Instead, it is at the local administrative center, Posto Leonardo, a relatively neutral setting that women from any Upper Xingu village can visit without invitation. One of the cofounders told me that this Women's Convention Center will serve as a place where women from all the local communities can meet to discuss problems they are facing. It's worth noting that Upper Xingu men do not yet have a permanent intergroup meeting house. At the opening day ceremonies, the women distributed free menstrual cups to the attendees, along with other swag. The creativity and initiative shown by these women will serve them well as they become increasingly integrated into a national and world culture that does not always willingly grant them as much agency and autonomy as their grandmothers enjoyed.

\section{References}

BASSO, Ellen B. 1985. A Musical View of the Universe: Kalapalo Myth and Ritual Performances. University of Pennsylvania Press.

CROCKER, William H.; CROCKER, Jean. 2004. The Canela: Kinship, Ritual, and Sex in an Amazonian tribe (2nd ed.). Califnornia: Wadsworth Publishing Company.

FRANCHETTO, Bruna. 1996. "Women among the Kuikuro." Translated by Christopher Peterson. Estudos Feministas, vol. 4, no. 1: 225-39.

FAUSTO, Carlos. 2016. "How Much for a Song? The Culture of Calculation and the Calculation of Culture." BRIGHTMAN, Marc; FAUSTO, Carlos; GROTTI, Vanessa. (Eds.). Ownership and Nurture: Studies in Native Amazonian Property Relations. New York: Berghahn Books, 133-155.

GREGOR, Thomas. 1977. Mehinaku: The Drama of Daily Life in a Brazilian Indian Village. Chicago: University of Chicago Press.

GREGOR, Thomas. 2008. Anxious Pleasures: The Sexual Lives of an Amazonian People. University of Chicago Press.

LEA, Vanessa R. 2013. "The Sound of Silence (Paul Simon)." Cadernos Pagu 41: 87-93. DOI 10.1590/S0104-83332013000200009

NOVO, Marina Pereira. 2019. "Dangerous desires: the affects (and affections) of cash transfer programs among the Kalapalo from the Aiha Village (Upper Xingu, Mato Grosso, Brazil)." In: BALEN, Maria Elisa; FOTTA, Martin. (Eds.). Money from the Government in Latin America. London and New York: Routledge, pp. 130-144.

NOVO, Marina Pereira. 2018. “Esse é o meu patikula”: uma Etnografia do Dinheiro e Outras Coisas entre os Kalapalo de Aiha'. São Carlos: PhD Thesis, Universidade Federal de São Carlos. 
OVERING, Joanna. 1986. "Men control women? The 'catch 22 ' in the analysis of gender." International Journal of Moral and Social Studies, vol. 1, no. 2: 135-156.

REGITANO, Aline de Paula. 2019. “Cuida Direitinho”: cuidado e corporalidade entre o povo Mehinako. Campinas: Master's Thesis, Universidade Estadual de Campinas.

WEIGHT, Michael D.; KEEFE, Earl. 2016. "Partible Paternity and Female Choice: Comment on Ellsworth et al." Current Anthropology, vol. 57, n. 1: 96-97. DOI $10.1086 / 684842$

WAUJA ONAPÃ (Wauja Song). 2021. Directed by Piratá Waurá, Associação Indígena Tulukai.

\section{about the author}

\section{Emilienne Ireland}

Research Associate at the Smithsonian Institution National Museum of Natural History in Washington, DC, and Director of the Wauja Language Project for The Americas Research Network (arenet.org). Emilienne has done ethnographic and linguistic research for the past forty years with the Wauja people of the Upper Xingu region of Brazil. She is now working with the grandchildren of her former Wauja teachers to produce ethnographic documentation of Wauja culture and history in the Wauja language. This indigenouslanguage documentation is being used as primary source material by Wauja university students and filmmakers, and in the village schools.

Statement of Authorship: The author is responsible for the ethnographic data collection and analysis, and for the writing as well.

Funding: Betty J. Meggers Research Grant, The Americas Research Network (arenet.org); Smithsonian Institution Recovering Voices Community Research Program; Foundation for Endangered Languages (FEL); Yale University Concilium on International and Area Studies

Received on August 17, 2021

Accepted on December 12, 2021 